\title{
A Jerusalem Synagogue Coping During the Coronavirus Pandemic: Challenges and Opportunities
}

\author{
Ephraim Shapiro $^{1}$ D $\cdot$ Livia Levine ${ }^{2} \cdot$ Avi Kay $^{2}$
}

Accepted: 3 November 2020 / Published online: 2 January 2021

(c) Springer Science+Business Media, LLC, part of Springer Nature 2021

\begin{abstract}
A diverse Modern Orthodox synagogue in Jerusalem continued to serve its congregants and maintain community despite closures and restrictions during the coronavirus pandemic. Members were surveyed in April 2020. There were minorities of members who were experiencing mental health issues, especially those less acculturated and no one surveyed received any professional mental health help. About a quarter of the members said that regular check-ins were important but some said they were not receiving enough of them. Synagogues can potentially serve as coping resources for congregants both during periods of crisis as well as during regular periods of operation.
\end{abstract}

Keywords Synagogue $\cdot$ Faith-based organizations $\cdot$ Coronavirus $\cdot$ Coping $\cdot$ Mental health

\section{Introduction}

Research has found that religious congregations can serve as resources to congregants, improving their members' health. The coronavirus crisis has impacted the lives of many as governments around the world implement guidelines altering interactions with others, including those that occur within the framework of religious organizations. In Israel, physical gatherings in religious congregations were not allowed for a period of almost two months and are currently (as of September 2020) restricted to small groups. These limitations presented many challenges for congregations interested in maintaining a sense of community and serving as a resource for congregants during a time when congregants may potentially have increased need for community because of direct and indirect stresses related to the coronavirus,

Ephraim Shapiro

eas97@caa.columbia.edu

1 Department of Health Systems Management, Ariel University, 4 Kiryat Hamada, 40700 Ariel, Israel

2 Department of Business Management, Jerusalem College of Technology, Jerusalem, Israel 
with concomitant effects on mental health. A diverse Modern Orthodox synagogue in Jerusalem attempted to continue to serve its congregants and maintain community virtually during this period.

\section{Religious Congregations and Members' Health}

An extensive body of research provides evidence of a generally positive relationship between religion and both physical and mental health (Ellison and Levin1998; Stark 2006; Koenig et al. 2012; Oman 2018; Ahrenfeldt et al. 2018). There are many aspects of religious life, but the features of religion with the strongest relationship to health are those related to community, often measured by congregational attendance (Powell et al. 2003; Koenig et al. 2012). Being part of a community has been associated with a variety of better health outcomes, especially among members of religious congregations (Putnam and Campbell 2010; Koenig et al. 2012; Shapiro and Sharony 2019; Foege 2019). Religious congregation members are more likely to experience a sense of community (Stroope 2011). The community can play a pivotal role in their lives, both in general and in particular for immigrants (Stark and Finke 2000; Foley and Hoge 2007).

Religious congregations are an important source of social capital, providing individuals with a network of social ties with like-minded individuals that share their beliefs and behaviors, their ideas and interests and their values and visions and may be associated with better health (Portes 1998; Putnam 2000; Pargament et al. 2001; Kadushin 2011; Koenig 2012 Foege 2019). Congregations' members interact with one another at prayer services, lectures and other activities that create bonds among them and can increase both the quantity and quality of social capital within the congregation. The social capital found within religious congregations is also associated with stronger mental health (Viladrich and Abdraido-Lanza 2009; Yeary et al. 2012; Shapiro and Sharony 2019). Involvement in religious congregations can play important roles in increasing social integration and social support (Rote et al. 2013), thereby reducing loneliness, which reduces stress, depression and suicide (Mushtaq et al. 2014).

In addition to increasing social resources, religious congregations can improve health and well-being of their members through direct initiatives. There is extensive evidence that faith-based health initiatives can have a positive impact on congregants, although they are typically found only in a minority of congregations. (Campbell et al. 2007; Trinitapoli et al. 2009; Viladrich and Abdraido-Lanza 2009; Arredondo et al. 2017; Schwingel and Gálvez 2016). Religious communities also contribute to better mental health outcomes in particular by addressing needs of their members, above and beyond serving as a physical place for communal worship (Min 1992; Stark and Finke 2000; Oman 2018).

Research concerning the connection between religious congregations and health has mostly focused on churches. (Koenig et al. 2012; Oman 2018;). As every religion has unique beliefs, practices, and social norms that can potentially affect the role of religious congregations in their members' health, it is important to examine how the above dynamic may vary among different religious traditions. 
There is at least some evidence of a relationship between involvement in Jewish communities and health outcomes (Rosmarin 2009a, b; Benjamins et al. 2011; Levin 2012, 2013, 2015; Litwin et al. 2017); but the topic has not been fully explored. There is also some evidence that Jews in the U.S. who are religiously involved may have fewer mental health stressors since the coronavirus outbreak (Pirutinsky et al. 2020).

While research regarding religiosity and its mental health outcomes among Jews often makes mention of the particular importance of behaviors such as synagogue attendance and study in Judaism as well as individual beliefs and attitudes, to our knowledge no study has directly examined the relationship of activities of Jewish congregations and their possible mental health benefits. Indeed, despite the extensive literature about the relationship between religion and health, there has been surprisingly little written about the role of synagogues in health, with almost no research taking place in Israel despite the potentially different role of synagogues there (Koenig et al. 2012; Itzhaki and Cnaan 2019a, b).

\section{Religious Congregations During the Coronavirus Period}

The nature of community and religious involvement for congregants has changed since the outbreak of the Coronavirus. Religious congregations were closed in many countries, including Israel, for an extended period. As of September 2020, when this article was written, there are still strict limits regarding the number of individuals who can be physically present at a synagogue, after their having been closed altogether for almost two months. At the same time that the physical services of religious congregations were restricted, there has been a greater need for assistance because of direct and indirect stresses of Corona. A recent study in Israel found high levels of anxiety and risk for depression as a result of several stressors connected with the coronavirus and related policies such as social isolation (Shapiro et al. 2020).

Alongside the mental health benefits of belonging to a religious community discussed above, are the potential negative effects of being physically distanced from such a community. A review of prior research has noted that religious struggles may be intensified during the Corona pandemic (Dein et al. 2020). Therefore, these synagogue closures and restrictions come at potentially great cost to congregants for whom face to face interactions with other congregants plays a central role in their lives (Vanderweel 2020). Orthodox Judaism places a heavy emphasis on the communal and social aspects of the religion as well as rituals (Heilman 2000). A sense of abandonment by or alienation from a framework that has previously anchored the individual can lead to negative mental health outcomes and difficulty coping with those outcomes (Pargament et al. 2001; Ellison and Lee 2010; O'Brien et al. 2019). Religious leaders have tried to be creative in terms of their religious functions such as virtual prayer services to maintain community (Frei-Landau 2020). However, it is not clear they have adequately addressed mental health stressors among congregants during the Corona pandemic. 


\section{Case Study: A Jerusalem Synagogue}

We studied the needs of members of a synagogue in central Jerusalem and the efforts of the synagogue to address these needs since the beginning of the coronavirus outbreak. These needs included: enlisting volunteers to check in on older members, streaming virtual shiurim (religious lessons), and organizing virtual prayer services.

The almost 150 family congregation was founded in 1962 and is run completely by lay leadership, with a rabbi who serves as its spiritual leader. The congregation can be categorized as "Dati Leumi" - which is roughly the Israeli equivalent to Modern Orthodox or "Centrist Orthodoxy," characterized by faithful adherence to traditional Jewish law, but differentiated from the ultra-Orthodox by its openness to Western knowledge and lifestyle (Lamm 1990). "Dati Leumi" characterizes about $12 \%$ of the Jewish population in Israel (Miskar 2017), yet this population has been studied less than other Jewish streams (Miskar 2017; Itzhaki and Cnaan 2019a, b). Further, this is an especially important population to study because people who belong to the Dati Leumi religious community may have greater health needs than those in the Secular or ultra-Orthodox communities (Brammli-Greenberg et al. 2018).

Before the corona-related lockdowns, most members of this synagogue attended the synagogue weekly for Friday night and Saturday morning Sabbath prayers and/or for weekly talks about Jewish texts, with many also attending daily prayer services. Thus, the closing of the synagogue may be viewed as a substantial change in the lives of its members. The synagogue's members tend to be in late adulthood, with its president estimating their average age at around 70. Many members are immigrants, although some arrived to Israel before they were adults.

\section{Study Objectives}

This study investigated in-depth the needs of congregants of a Jerusalem synagogue, how they coped with the coronavirus impact, and in particular, to what extent their needs were addressed by the synagogue.

\section{Specifically, The Study Asked}

1. What factors impact synagogue congregants' mental well-being during the Coronavirus period and how do they cope with stressors?

2. To what extent can the synagogue meet congregants' needs in terms of mental health and well-being?

3. Do needs vary by key demographic categories?

\section{Methodology}

The study made use of both quantitative and qualitative methods; for the quantitative section, one hundred and fifty families of the congregation being studied were sent an online survey at the end of April 2020. The survey asked about mental health 
stressors and reactions related to the Coronavirus outbreak. Specifically, the survey addressed possible economic, social and health related changes associated with the coronavirus as well as feelings of anxiety and depression. The original English survey was translated into Hebrew by a professional translator. Respondents had the option of completing the survey in either English or Hebrew.

The questions concerning mental health and stressors were taken from previously validated questionnaires such as the Patient Health Questionnaire-2 depression screening tool (Mitchell et al. 2016) and included items used in previous research related to epidemics, such as severe acute respiratory syndrome (SARS) (Wong et al. 2007). Respondents were also asked to rate the level of anxiety they experienced within the last two weeks on a scale of 1 to 5 , with 3 being considered moderate anxiety and 4 or 5 as high or very high anxiety.

For the purposes of our study, we wanted to be conservative in identifying people who may need help and should be screened for depression, so we used a PHQ cutoff with low specificity, using a score of two or greater, as is done in order that fewer potential cases of depression are missed (Manea et al. 2016).

Congregants were also asked about sources of assistance and about a variety of perceived needs during this period. In addition, relevant demographic data such as gender, age, education, occupation and marital status was gathered. After collecting the data online, we performed univariate and bivariate analyses, using Chi square and $t$ tests to test for statistically significant differences between key subgroups.

Data gathered through the survey was supplemented by a qualitative portion of the research. We used a qualitative paradigm, eliciting information about congregants' construction of reality during this period, thus providing additional insight into their experiences and social environment (Denzin and Lincoln 2000). This was accomplished through a content analysis of information sources, both oral and written. This method is appropriate for subjective interpretation of text content through the systematic coding and identification of themes (Hsieh and Shannon 2005). Data sources for the content analysis included emails to congregants, participant observation in congregational activities and conversations with congregational leaders and members (among whom are two of this paper's authors). Data were then analyzed for themes and integrated with relevant results from the quantitative portion of the research.

The study was approved by the Ariel University Ethics Committee and all participants consented in writing to participate in the study.

\section{Findings}

\section{Description of Survey Respondents}

A description of the sample can be found in Table 1. The survey was sent to all 150 member families of the synagogue. Of the 51 respondents, 28 answered in Hebrew and 23 in English; 20\% of respondents were born in Israel. Most of the others were born in Europe or North America, with about $80 \%$ having moved to Israel 25 or 
Table 1 Descriptive statistics for key demographic, religion, and immigrant measures

\begin{tabular}{|c|c|c|}
\hline Variable & Category & Percent $(N)$ \\
\hline \multirow[t]{2}{*}{ Gender } & Male & $56 \%(29)$ \\
\hline & Female & $44 \%(22)$ \\
\hline \multirow[t]{3}{*}{ Age } & $18-64$ & $16 \%(8)$ \\
\hline & $65-79$ & $49 \%(25)$ \\
\hline & $80+$ & $35 \%(18)$ \\
\hline \multirow[t]{2}{*}{ Marital status } & Married. & $72 \%(36)$ \\
\hline & Never married/formerly married & $28 \%(14)$ \\
\hline Children under 18 in household & Yes & $10 \%(5)$ \\
\hline Education & College Graduate & $63 \%(32)$ \\
\hline \multirow[t]{2}{*}{ Employment } & Employed & $35 \%(18)$ \\
\hline & Not working/Retired & $65 \%(33)$ \\
\hline \multirow[t]{4}{*}{ Country of Birth } & Israel & $22 \%(11)$ \\
\hline & Europe & $45 \%(23)$ \\
\hline & North America & $25 \%(13)$ \\
\hline & Other & $6 \%(3)$ \\
\hline \multirow[t]{3}{*}{ Years in Israel (immigrants) } & $<24$ Years & $20 \%(8)$ \\
\hline & 25-49 Years & $38 \%(19)$ \\
\hline & $>50$ Years & $42 \%(21)$ \\
\hline \multirow[t]{4}{*}{ Health Status } & Excellent & $18 \%(9)$ \\
\hline & Very good & $37 \%(19)$ \\
\hline & Good & $35 \%(18)$ \\
\hline & Fair or poor & $10 \%(5)$ \\
\hline
\end{tabular}

Total $N=51$

more years ago. Almost everyone identified themselves as Dati (similar to Modern Orthodox).

The majority of the respondents were over the age of 65 . This is similar to the actual average age of the congregation, according to its president's estimate. Only about $10 \%$ of respondents had children under 18 living with them; $56 \%$ of respondents were male and roughly $71 \%$ of respondents were married. The respondents were very well educated, with many having a master's degree or doctorate, $63 \%$ were retired, $20 \%$ self-employed, and the rest were salaried workers.

\section{Mental Health and Well-being}

Respondents were asked a number of questions related to anxiety, stress and risk for depression. Results can be found in Table 2 . There was a minority among respondents experiencing possible mental health problems, especially among those taking the survey in English. About $27 \%$ of the sample also said they felt upset or panicky. Of the 23 people answering in English, four of them felt high or very high anxiety and eight of them felt moderate anxiety. None of the 28 people answering in Hebrew 
Table 2 Mental health status

\begin{tabular}{llll}
\hline & $\begin{array}{l}\text { Hebrew (percent- } \\
\text { age and sample size) } \\
N=28\end{array}$ & $\begin{array}{l}\text { English (percent- } \\
\text { age and sample size) } \\
N=23\end{array}$ & $\begin{array}{l}\text { Overall (percentage } \\
\text { and sample size) } \\
N=51\end{array}$ \\
\hline $\begin{array}{l}\text { Reported moderate, high or very } \\
\text { high anxiety** }\end{array}$ & $14 \% *(4)$ & $52 \%(12)^{*}$ & $31 \%(16)$ \\
$\begin{array}{l}\text { Reported sometimes feeling } \\
\text { upset/panicky } \\
\begin{array}{l}\text { Sometimes feel like they're fall- } \\
\text { ing apart** } \\
\text { At risk for depression }\end{array}\end{array}$ & $4 \%(1)$ & $29 \%(8)$ & $27 \%(14)$ \\
\hline
\end{tabular}

$* p<.05 * * p<.01$

${ }^{\mathrm{a}}$ Depression risk measured using PHQ2 screening tool, using cutpoint of 2 or greater

felt a high level of anxiety and only four felt even moderate anxiety. The differences between the two groups were statistically significant $(p<.05)$.

About 22\% of the English group responded that they at least sometimes felt they were going to pieces, as compared to just $4 \%$ of the Hebrew group $(p<.05)$. Conversations with congregants supported these findings of generally low levels of anxiety among the synagogue's members but potential mental health issues among some congregants, especially immigrants.

Among all respondents, $18 \%$ showed potential risk for major depression (measured by a PHQ score $>=2$ ). As with anxiety, there was a higher level of depression risk found among the English group (26\%) as compared to the Hebrew group (13\%); though the difference was not statistically significant.

We also examined both direct and indirect stressors associated with the virus itself or related government policies that have been associated with higher levels of anxiety and depression risk (Shapiro et al. 2020). Results can be found in Table 3. Forty-three percent of respondents knew someone infected or were, themselves, infected with Corona. Almost 35\% of all respondents expressed a high or very high level of worry that family and friends will be infected, with $44 \%$ of those responding in English expressing such worry as opposed to $29 \%$ in Hebrew. In addition, $31 \%$ had at least a high level of concern about their health or that of their family and friends. Among English respondents, 52\% expressed worries about their health or that of their family and friends, as compared to $14 \%$ in the Hebrew group (significant at $\mathrm{p}<.05$ ).

About a third of respondents said they were afraid to go the hospital for consultations. Further, while 30\% of those responding in English felt high or very high stress because of the restrictions on daily life, not one of the Hebrew respondents did (significant at $\mathrm{p}<.01$ ). For example, one such member expressed great stress regarding not being able to leave her apartment and that even simple tasks such as getting a daily newspaper required coordination among neighbors. However, almost no one expressed great worry about economic concerns, perhaps related to the fact that most respondents were retired. 


\section{Coping Methods}

Despite the anxiety, stresses and risk for depression noted, almost none of the respondents sought professional mental health care. When asked the reason, they responded that they did not think they needed it, although one person noted that no "virtual" option was available to her.

Among those who did try to cope with the stresses of the period, many turned to family and friends or tried to handle the situation themselves. In the survey, this was true of both the Hebrew and the English group, although in conversations with members the assistance of family and friends was mentioned more by Hebrew-speakers: A number of the English speakers, but not Hebrew speakers, also mentioned use of social media, either posting or reading others posts, statistically significant difference between the groups. One person from each group mentioned taking medications and only one person said they turned to a religious or spiritual leader for help.

\section{Demographic Variations}

While there were variations in results by survey language, we found almost no statistically significant variations for measures of stress, anxiety and depression risk by other key demographic categories. With regard to gender, the only significant association was that women reported higher stress from daily restrictions $(p<.05)$. For age, only worry about health was even marginally significant, with those in the oldest age category expressing the highest level of worry. Almost none of the outcomes measures were associated with education level or marital status at a statistically significant level, although it should be noted that it was a relatively small sample.

\section{Assistance/Programming}

The survey also addressed needs that congregants may have had (see Table 4). About a quarter of the members who responded to the question, said that regular phone visits and/or "check-ins" were important to them, at least to some extent. Very little difference was found between those taking the survey in English and in Hebrew. However, in the open-ended survey questions or in subsequent conversations with members, a number of those in the English group noted that they would like more visits or "checks-ins" than they received. Those in the Hebrew speaking group typically told us that they have family members providing such assistance.

Respondents expressed very little need for help with childcare, studies, or employment. This is not surprising given the demographic profile of those surveyed.

In terms of activities, almost half of those who expressed an opinion had moderate to great interest in virtual lectures or religious classes, with several people saying they hoped these would continue even after in-person classes were allowed. Some people suggested having more lectures given by the congregation's members and outsiders, in addition to those given by the rabbi of the congregation. According to the synagogue's leadership, the virtual prayer services had far more attendees than the lectures. In addition to the spiritual aspects, one possible reason for 


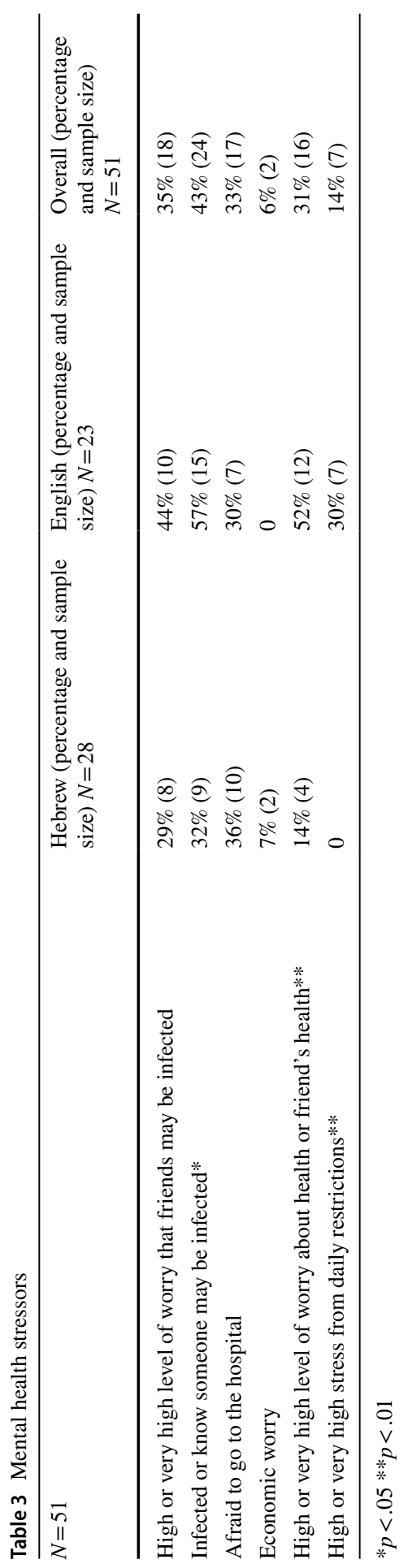


the popularity of the prayer services is that they are more interactive, with participants singing and even dancing together, with some members saying the services enhanced a sense of community.

Community plays an important role for respondents. About-two-thirds of respondents said that a sense of community was important or very important to them (Table 4). The absence of a physical place of congregation was felt. Members spoke about missing going to synagogue and the social as well as religious roles it filled in their lives

The synagogue we studied has many community-building activities unrelated to religious functions, something that was noted by several members. For example, there are programs such as "Friends Meet Friends" in which older members tell their life stories, "Sabbath Meeting," dinners where some members host others to get to know each other better and a two-day group excursion outside of Jerusalem.

\section{Discussion}

This study examined a Jerusalem synagogue in order to try to assess the impact of membership in and activities of that synagogue related to several mental health outcomes during the COVID-19 outbreak. As may have been expected from the literature (Koenig et al. 2012), we found less anxiety, risk for depression, and stress among congregants overall as compared to the general Israeli population (Shapiro et al. 2020). However, this does not mean that there is no reason to be concerned about congregants' health as there are some subgroups where there was evidence of problems. An important minority of congregants, primarily among those who answered the survey in English, were still at risk for significant mental health issues.

Table 4 Community activities/support

\begin{tabular}{llll}
\hline & $\begin{array}{l}\text { Hebrew (percent- } \\
\text { age and sample size) } \\
N=28\end{array}$ & $\begin{array}{l}\text { English (percentage } \\
\text { and sample size) } \\
N=23\end{array}$ & $\begin{array}{l}\text { Overall (percentage } \\
\text { and sample size) } \\
N=51\end{array}$ \\
\hline $\begin{array}{l}\text { Sense of Community Important } \\
\text { or Very Important }(N=51)\end{array}$ & $47 \%(13)$ & $87 \%(20)$ & $65 \%(33)$ \\
Check In $(N=39)$ & $24 \%(3)$ & $18 \%(4)$ & $18 \%(7)$ \\
Visits $(N=40)$ & $18 \%(3)$ & $17 \%(4)$ & $18 \%(7)$ \\
Help with shopping $(N=37)$ & $13 \%(2)$ & $19 \%(5)$ & $19 \%(7)$ \\
Help finding a job $(N=35)$ & 0 & 0 & 0 \\
Virtual lectures/lessons*s & $11 \%(1)$ & $58 \%(11)$ & $46 \%(12)$ \\
Virtual Prayer Services $(N=17)$ & NA & $47 \%(8)$ & $47 \%(8)$ \\
\hline
\end{tabular}

Missing counted as not interested

Interest defined as 3 or above on 5 points scale

Hebrew speakers were not asked about virtual prayer services

$* p<.05$ 
While there is a dearth of research concerning synagogues and mental health during the coronavirus outbreak, a study of 419 Orthodox Jews in the United States during this period also found that mental health may be better among those more religious and attributed this to increased resiliency (Pirutinsky et al. 2020). The current study complements those findings by focusing on the communal aspect of religious life rather than personal beliefs as well as examining one congregation in depth.

The congregants indicated that community plays an important role in their lives, and that groups like their synagogue congregation continue to play an important role in their sense of community, despite the limited physical interactions. While the term "social distancing" has been used during the corona pandemic to denote lack of physical proximity to someone, results from this survey show that the term may be imprecise as one can feel socially close to others despite being physically distanced.

Important minorities of both the Hebrew and English respondent groups expressed a desire to have others in the congregation check in and/or visit them, at least virtually, as well as help with practical tasks such as shopping. There was also interest in virtual activities such as prayer services, especially among the English group.

The congregation has taken important steps to try to address members' needs and interests. When the lockdown began, the synagogue acted on a number of fronts: Inquiries were made by email and phone as to whether there were members in quarantine or otherwise have trouble getting out and in need of provisions for the Sabbath. Regular communications about lectures and other activities that had changed to virtual formats were sent to members. A group of volunteers from the synagogue was organized to phone older single members regularly.

It should be noted that there may be opportunities for the congregation to do more in this area. A number of members did not feel their needs were being met and some said they were not checked up on enough. Others said they would have liked to volunteer but were not asked. There were also subgroups that felt they would have liked special outreach, such as a Holocaust survivor who mentioned this.

However, the synagogue leadership recognized there was a need to do more (Pomerantz 2020) and the very fact that a synagogue supported the needs assessment presented here appears to be unusual even during normal times (Itzhaki and Cnaan 2019a) and all the more so during a pandemic. The president of the synagogue wrote a blog article intended for other synagogues as well as a broader audience, describing its actions during the pandemic. He presented the evaluation we performed as a potential model for how other synagogues in Israel and elsewhere might regularly assess congregants' health and other needs (Pomerantz 2020).

The results of our study were given to the synagogue board both in the form of a report and a presentation to board members, so that they could understand the effectiveness of the synagogue's actions in meeting congregants' needs during the pandemic and discuss how better to do so in the future.

The synagogue's membership is disproportionately older; a group not only at great risk of being infected by the virus but also at potentially greater risk of associated mental health issues (Bentur and Heymann 2020). Although a significant minority of our respondents were at potential risk for serious mental health problems, only one person attempted to get mental health care from a professional. These 
results are similar to prior findings about underuse of mental health services among Israelis (Elroy et al. 2017; Shapiro et al. 2020). However, in this context it raises larger questions about the lay leadership's potential role in addressing congregants' unmet needs.

It is not clear what might be the appropriate role of synagogues in areas not clearly tied to religion; such as contributing to the mental health of their congregants both in general and during times of crisis such as the coronavirus pandemic. There is an extensive body of research showing that religion can be a source of coping and resilience (Rosmarin et al. 2009a, b; Pargament 2013, Frei-Landau 2020). However, the synagogue's role in its members' ability to cope with stressors both in general and during a crisis such as the coronavirus pandemic remains unclear with some claiming that addressing mental health needs goes beyond the appropriate mission and expertise of a synagogue, Indeed, while the results of the survey were overall favorably received by the synagogue's board, some board members thought that responsibility for the mental health needs of individual congregants is not a clearly defined goal of the synagogue and falls outside the purview of the leadership's responsibility and capability.

However, as noted, involvement in a religious community has been shown to potentially reduce loneliness and other mental health stressors (Koenig et al.; Rote et al. 2013). Therefore, we would argue that there is an opportunity for synagogues to leverage their social capital and realize their potential to provide mental health support for their congregants. There have been health-focused initiatives in churches such as mental health ministries (Hankerson and Wesissman 2012) and these may be appropriate for synagogues as well. In addition to pastoral counseling for some issues (Flannelly et al. 2006), synagogues can potentially play a role in identifying congregants with serious mental health issues and making necessary referrals to the mental health care system.

Further, this type of program is consistent with Jewish tradition as reflected in the Talmudic verse that "he who saves one soul saves the entire world" (Tractate Sanhedrin, page 37a). In addition, far from Judaism being antagonistic to working with the health care system, healthcare can indeed be considered a societal obligation mandated by Jewish law (Stadlan 2020). Thus, it seems that it would be both of practical benefit and well within the norms of Jewish tradition for synagogues to play a role in facilitating people receiving appropriate mental health care.

The synagogue in this study serves as a particularly interesting case study, in that Israeli synagogues typically serve only as a place of worship (Davidovitch 2019), and do not seek to also be community centers involved in other parts of members' lives-a model commonly found in the United States and many other Western countries, (Edelstein et al. 2018; Wertheimer 2018). While there have been some initiatives in Israel to transform synagogues in Israel to more closely resemble the diaspora model, such an orientation still seems to be unusual in Israel (Davidovitch 2019; Tzohar 2020). Focusing more on community and congregational well-being would bring Israeli synagogues closer to the American model and more capable of assisting congregants with unmet needs. 


\section{The Role of Acculturation in Mental Health Among Synagogue Members}

Congregants' demographic characteristics are important when considering the individual's needs both during a period such stress is being experienced due to the coronavirus, as well as in more normative periods. It is noteworthy that despite more than half of the sample being over the age of seventy and at high risk, with many of them being single women more likely to experience loneliness (Beal 2006), we did not find major differences in findings by age and gender.

In contrast, the language in which respondents chose to fill out the survey was associated with a number of differences in mental health stressors and risks at a statistically significant level. This may be because feeling like an outsider can cause stress, and acculturation is associated with lower psychological distress (Yoon et al. 2011). It may also reflect the breadth and depth of the social resources in the general community that are available to these individuals.

Differences in mental health issues between the English and Hebrew group may also be related to cultural differences. Native-born Israelis or those who immigrated during their youth may consider themselves to be mentally tough, having grown up in a hostile region while the English speakers may be more willing to reveal vulnerability. Those growing up in Israel may have grown more accustomed to stresses because of wars and terrorist attacks (Stein et al. 2018). In addition, there is a lack of appropriate use of mental health services in Israel (Elroy et al. 2017), which may make it be less acceptable for native-born Israelis or those more acculturated to acknowledge and discuss mental health issues.

Interestingly, unlike language, an analysis of the impact of time and age of migration on mental health outcome measures yielded no clear associations. Our hypothesis is that language of choice is an appropriate measure of acculturation, and may be associated with mental health issues and needs (Derr 2016). Indeed, one study found that language competence was a stronger predictor of adjustment than the other aspects of acculturation (Sun-Mee 2006). There may also be practical benefits to language acculturation. Those more comfortable using Hebrew, which in our sample were primarily members born in Israel or in non-English speaking countries, may be better able to understand news and to obtain both useful information and resources. For these reasons, it is not surprising that those in our sample who had greater acculturation, as indicated by choice of survey language, seemed to have greater mental resilience during the pandemic.

Synagogues can be catalysts for increasing bridging social capital as they can serve as intermediaries between individuals and other parts of the community, both religious and not specifically religious. They can therefore potentially play an especially important mental health role for less acculturated immigrants. This is consistent with literature that shows that churches can be an important source of social capital and play important roles in integrating immigrants into society (Foley and Hoge 2007).

Interestingly, although the English language respondents had more potential health issues and felt a stronger need for community, the Hebrew language cohort expressed a similar desire for people to check up on them and visit them despite 
many of them having family in the area. The reasons for this are not clear but perhaps the need for community goes beyond merely practical issues.

\section{Limitations/Additional Research}

A primary limitation of this study is related to data collection, resulting in responses from about a third of the synagogue's approximately 150 families. The sample size of survey respondents was therefore too small to perform multivariable analyses. As a result, we could not identify all potential confounders and reasons for associations uncovered. However, we think that the study allowed for the identification of both overall needs and sub-groups that likely have greater needs.

It is important to note that as we often had a single email address for a couple, it is not clear whether some respondents were answering on behalf of a partner. In addition, as the list we received included people who had moved and may no longer be active members of the congregation, it is impossible to calculate the precise response rate.

While our sample appeared to be representative, members of this synagogue are disproportionally older, foreign-born and better educated than the general Israeli public. The study helped shine a light on the needs and coping mechanism of an older demographic which may have special stressors because of the coronavirus. However, additional research is needed in order to examine to what extent findings would be generalizable to other Israeli synagogues with different demographic makeups.

The findings may also not be fully generalizable to synagogues in the diaspora, which may serve different roles for its members. Our study focused on Hebrew and English speakers but it would have useful to also focus on congregants with other primary languages, such as French or German.

Finally, survey length was limited in order to increase the response rate. It would be useful to repeat the study with more extensive measures, that could better analyze the impact of acculturation and language; as well as preferences and needs related to synagogue affiliation and activities.

\section{Conclusion}

Religious identification can bring with it both a sense of belonging to something greater than oneself, as well as association with a formal organization. The belonging does not, necessarily, require physical interactions among group members and may also go beyond purely religious activities.

In our study, congregants reported lower anxiety overall and depression risk compared to the general Israeli public. However, this was not true of all members and some of them may not be getting appropriate mental health care. The study raises larger questions about the responsibility of congregations to act regarding 
the mental health needs of its members. As noted, this is something that is not typically addressed in synagogues, in general, and particularly not in Israel.

This in-depth study of how one synagogue is dealing with the challenges associated with the ongoing coronavirus pandemic is a pioneering attempt to examine the potential role such organizations can play in the lives of their congregants. We think that a greater understanding of to what extent those efforts were successful can provide important lessons as to how congregations can better serve as resources both during unusual periods such as the current one, as well as in general.

\section{Compliance with Ethical Standards}

Conflict of interest We have no relevant conflicts of interest.

Ethical Approval This paper was written in compliance with our institutions' ethical standards, and without a source of funding.

\section{References}

Ahrenfeldt, L. J., Möller, S., Hvidt, N. C., \& Lindahl-Jacobsen, R. (2018). Religiousness and lifestyle among Europeans in SHARE. Public health, 165, 74-81.

Arredondo, E. M., Elder, J. P., Haughton, J., Slymen, D. J., Sallis, J. F., Perez, L. G., et al. (2017). Fe en acción: Promoting physical activity among churchgoing Latinas. American Journal of Public Health, 107(7), 1109-1115. https://doi.org/10.2105/AJPH.2017.303785.

Beal, C. (2006). Loneliness in older women: A review of the literature. Issues in Mental Health Nursing, 27(7), 795-813.

Benjamins, M., Ellison, C., Krause, N., \& Marcum, J. (2011). Religion and preventive service use: Do congregational support and religious beliefs explain the relationship between attendance and utilization. Journal of Behavioral Medicine, 8, 462-476.

Bentur, N., \& Heymann, A. D. (2020). Depressive symptoms and use of health services among older adults in Israel. Israel Journal of Health Policy Research, 9, 15. https://doi.org/10.1186/s1358 4-020-00374-5.

Brammli-Greenberg, S., Glazer, J., \& Shapiro, E. (2018). The inverse U-shaped religion-health connection among Israeli Jews. Journal of Religion and Health, 57(2), 738-750. https://doi. org/10.1007/s10943-018-0577-3.

Campbell, M. K., Hudson, M. A., Resnicow, K., Blakeney, N., Paxton, A., \& Baskin, M. (2007). Church-based health promotion interventions: Evidence and lessons learned. Annual Review of Public Health, 28, 213-234.

Davidovitch, N. (2019). The Function of the synagogue in leisure culture. Philosophy, 9(1), 1-15.

Dein, S., Loewenthal, K., Lewis, C. A., \& Pargament, K. I. (2020). COVID-19, mental health and religion: An agenda for future research. Mental Health, Religion and Culture, 23(1), 1-9.

Denzin, N. K., \& Lincoln, Y. S. (2000). Introduction: Entering the field of qualitative research. In N. K. Denzin \& Y. S. Lincoln (Eds.), Handbook of qualitative research (pp. 1-16). Thousand Oaks: Sage Publications.

Derr, A. S. (2016). Mental health service use among immigrants in the united states: A systematic review. Psychiatric Services (Washington, D.C.), 67(3), 265-274.

Edelstein, O. E., Band-Winterstein, T., \& Bachner, Y. G. (2018). Profile and burden of care among caregivers of Ultra-Orthodox frail elders. Aging and Mental Health, 22(5), 639-645.

Ellison, C. G., \& Lee, J. (2010). Spiritual struggles and psychological distress: Is there a dark side of religion. Social Indicators Research, 98(3), 501-517. 
Ellison, C. G., \& Levin, J. S. (1998). The religion-health connection: Evidence, theory, and future directions. Health Education and Behavior, 25(6), 700-720. https://doi.org/10.1177/1090198198 02500603.

Elroy, I., Samuel, H., \& Rosen, B. (2017). Mental health services in Israel: needs, patterns of utilization and barriers-Survey of the general adult population. Jerusalem: Myers-JDC-Brookdale Institute.

Flannelly, K. J., Stern, R. S., Costa, K. G., Weaver, A. J., \& Koenig, H. G. (2006). Rabbis and health: A half-century review of the mental and physical health care literature:1950-1999. Pastoral Psychology, 54(6), 545-554.

Foege, W. (2019). Positive and negative influences of religion, culture, and tradition in public health. American Journal of Public Health, 109(3), 378.

Foley, M., \& Hoge, T. (2007). Religion and the New Immigrants: How faith communities form our newest citizens (p. 2007). New York: Oxford University Press.

Frei-Landau, R. (2020). When the going gets tough, the tough get-creative. Psychological Trauma Theory, Research, Practice and Policy, 12, S258-S260. https://doi.org/10.1037/tra0000822.

Hankerson, S. H., \& Weissman, M. M. (2012). Church-based health programs for mental disorders among African Americans: A review. Psychiatric services (Washington, D.C.), 63(3), 243-249. https://doi.org/10.1176/appi.ps.201100216.

Heilman, S. C. (2000). Defenders of the faith: Inside ultra-orthodox Jewry. Berkeley: University of California Press.

Hsieh, H., \& Shannon, S. (2005). Three approaches to qualitative content analysis. Qualitative Health Research, 15(9), 1277-1288.

Itzhaki, Y., \& Cnaan, R. A. (2019a). Determinants of sense of community in congregations. Journal of community psychology, 47(5), 1210-1224.

Itzhaki, Y., \& Cnaan, R. A. (2019b). Determinants of congregational attendees' psychological outcomes. Journal of Religion and Health, 5, 1-19. https://doi.org/10.1007/s10943-019-00803-z.

Kadushin, C. (2011). Social networks and jews. Contemporary Jewry, 31(1), 55-73.

Koenig, H. G. (2012). Religion, spirituality, and health: The research and clinical implications. ISRN Psychiatry, 2012, 278730. https://doi.org/10.5402/2012/278730.

Koenig, H., King, D., \& Carson, V. (2012). Handbook of religion and health. New York: Oxford University Press.

Lamm, N. (1990). Torah Umadda: The encounter of religious learning and worldly knowledge in the Jewish tradition. New York: Jason Aronson.

Levin, J. (2012). Religion and physical health among older Israeli Jews: Findings from the SHARE-Israel study. The Israel Medical Association Journal IMAJ, 14(10), 595-601.

Levin, J. (2013). Religious observance and well-being among Israeli Jewish adults: Findings from the israel social survey. Religions, 4(4), 469-484.

Levin, J. (2015). Religious differences in self-rated health among US Jews. Journal of Religion and Health, 54(2), 765-782.

Litwin, H., Schwartz, E., \& Avital, D. (2017). Religiosity and well-being among older Jewish Israelis: Findings from SHARE. Journal of Religion, Spirituality and Aging, 29(2-3), 208-223.

Manea, L., Gilbody, S., Hewitt, C., North, A., Plummer, F., Richardson, R., et al. (2016). Identifying depression with the PHQ-2: A diagnostic meta-analysis. Journal of Affective Disorders, 203, 382-395.

Min, P. G. (1992). The structure and social functions of Korean immigrant churches in the united states. International Migration Review, 26, 1370-1394.

Miskar Institution, Israel (2017). The modern orthodox population in Israel. Retrieved August 2020, from https://www.miskar.co.il/he/home. [Hebrew].

Mushtaq, R., Shoib, S., Shah, T., \& Mushtaq, S. (2014). Relationship between loneliness, psychiatric disorders and physical health. Journal of Clinical and Diagnostic Research, 8(9), 1-4.

O'Brien, B., Shrestha, S., Stanley, M. A., Pargament, K. I., Cummings, J., Kunik, M. E., et al. (2019). Positive and negative religious coping as predictors of distress among minority older adults. International Journal of Geriatric Psychiatry, 34(1), 54-59.

Oman, D. (Ed.). (2018). Why religion and spirituality matter for public health: Evidence, implications, and resources. New York: Springer.

Pargament, K. I. (2013). APA handbook of psychology, religion. And Spirituality: American Psychological Association. 
Pargament, K. I., Koenig, H. G., Tarakeshwar, N., \& Hahn, J. (2001). Religious struggle as a predictor of mortality among medically ill elderly patients: A 2-year longitudinal study. Archives of Internal Medicine, 161, 1881-1885.

Pirutinsky, S., Cherniak, A. D., Rosmarin, D. H. (2020). COVID-19, mental health, and religious coping among american orthodox jews [published online ahead of print, $2020 \mathrm{Jul} 23$ ]. J Relig Health. https ://doi.org/10.1007/s10943-020-01070-z.

Pomerantz, S. (2020). COVID 19 How did People fare retrieved from https://blogs.timesofisrael.com/ covid-19-how-did-people-fare/.

Portes, A. (1998). Social capital: Its origins and applications in modern sociology. Annual Review of Sociology, 24(1), 1-24.

Powell, L. H., Shahabi, L., \& Thoresen, C. E. (2003). Religion and spirituality. Linkages to physical health. The American Psychologist, 58(1), 36-52.

Putnam, R. D. (2000). Bowling Alone. New York: Simon and Schuster.

Putnam, R. D., \& Campbell, D. E. (2010). American Grace: How Religion Divides and Unites US. New York: Simon and Shuster.

Rosmarin, D. H., Krumrei, E. J., \& Andersson, G. (2009a). Religion as a predictor of psychological distress in two religious communities. Cognitive Behaviour Therapy, 38(1), 54-64.

Rosmarin, D. H., Pargament, K. I., \& Mahoney, A. (2009b). The role of religiousness in anxiety, depression, and happiness in a Jewish community sample: A preliminary investigation. Mental Health, Religion and Culture, 12(2), 97-113.

Rote, S., Hill, T. D., \& Ellison, C. G. (2013). Religious attendance and loneliness in later life. The Gerontologist, 53, 39-50.

Schwingel, A., \& Gálvez, P. (2016). Divine interventions: Faith-based approaches to health promotion programs for Latinos. Journal of Religion and Health, 55(6), 1891-1906.

Shapiro, E., Levine, L., \& Kay, A. (2020). Mental health stressors in Israel during the coronavirus pandemic. Psychological Trauma Theory, Research, Practice and Policy, 12(5), 499-501.

Shapiro, E., \& Sharony, C. (2019). Religious and social capital and health. In S. Folland \& E. Nauenberg (Eds.), The Elgar companion of social capital and health. Cheltenham: Edward Elgar Publishing.

Stadlan, N (2020). Is there a communal obligation to provide access to Healthcare? Analysis of a Halakhic minimum. Annual Review of Studies in Judaism, Humanities and the Social Sciences.

Stark, R. (2006). Economics of religion. In R. A. Segal (Ed.), The Blackwell companion to the study of religion (pp. 47-67). Oxford: Blackwell.

Stark, R., \& Finke, R. (2000). Acts of faith: Explaining the human side of religion. Berkeley: University of California Press.

Stein, J. Y., Levin, Y., Gelkopf, M., Tangir, G., \& Solomon, Z. (2018). Traumatization or habituation? A four-wave investigation of exposure to continuous traumatic stress in Israel. International Journal of Stress Management, 25(S1), 137-153.

Stroope, S. (2011). How culture shapes community: Bible belief, theological unity, and a sense of belonging in religious congregations. The Sociological Quarterly, 52, 568-592. https://doi.org/10.111 1/j.1533-8525.2011.01220.x.

Sun-Mee, K. (2006). Measurement of acculturation, scale formats, and language competence: Their implications for adjustment. Journal of Cross Cultural Psychology, 37(6), 669-693.

Trinitapoli, J., Ellison, C. G., \& Boardman, J. D. (2009). US religious congregations and the sponsorship of health-related programs. Social Science and Medicine, 68(12), 2231-2239.

Tzohar (2020). https://tzohar-eng.org/?

VanderWeele T.J. (2020). Love of Neighbor During a Pandemic: Navigating the Competing Goods of Religious Gatherings and Physical Health [published online ahead of print, 2020 May 13]. J Relig Health. 2020; 1-7.

Viladrich, A., \& Abdraido-Lanza, A. (2009). Religion and mental health among minorities and immigrants in the US. In S. Loue \& M. Sajatovic (Eds.), Determinants of minority mental health and wellness. New York City: Springer.

Wertheimer, J. (2018). The New American Judaism: How jews practice their religion today. Princeton: Princeton University Press.

Wong, T. W., Gao, Y., \& Tam, W. W. S. (2007). Anxiety among university students during the SARS epidemic in Hong Kong. Stress and Health, 23(1), 31-35. https://doi.org/10.1002/smi.1116.

Yeary, K., Ounpraseuth, S., Moore, P., Bursac, Z., \& Greene, P. (2012). Religion, social capital, and health. Review of Religious Research, 54(3), 331-347. 
Yoon, E., Langrehr, K., \& Ong, L. Z. (2011). Content analysis of acculturation research in counseling and counseling psychology: A 22-year review. Journal of Counseling Psychology, 58, 83-96. https://doi. org/10.1037/a0021128.

Publisher's Note Springer Nature remains neutral with regard to jurisdictional claims in published maps and institutional affiliations. 